if indeed equalled, in riches elsewhere-such riches, for example, as the Gothic buildings or the village churches with their painted decorations, to which Sir Charles referred. Since attention was directed recently to the danger which threatens the antiquities of the island, an inspector of antiquities has been appointed; this is only a partial discharge of the responsibility entailed by Britain's occupation of Cyprus since 1878, and its formal status as a colony since 1925, now that the inhabitants have fallen on evil days through the economic depression. On historical and æsthetic grounds, the Cyprus Monuments Fund (6 Pall Mall, London, S.W.1), for which several thousand pounds will be needed, deserves the fullest support.

\section{Elements and Isotopes}

The first Friday evening discourse of the new session at the Royal Institution was delivered on November 2 by Dr. F. W. Aston, who took as his subject "Elements and Isotopes". That a chemical element could consist of isotopes of different atomic mass was first observed by Soddy when working on the products of radioactivity. Proof that this was true of the elements generally could only be obtained by direct atomic analysis. This was achieved by the mass-spectrograph, and with it the search for isotopes has been carried on continuously for the past fifteen years. Wide differences of properties among the elements necessitate very varied methods of obtaining the atomic rays required for the analysis. In some cases the technical difficulties are great; it is only during the last year that satisfactory results have been obtained with the rare earth group. Of the common elements, all but four, palladium, iridium, platinum and gold, have now been analysed and some 247 isotopes identified, a few by less direct optical methods. Elements of odd atomic number appear curiously limited to two isotopes, but elements of even atomic number can have many more, eleven in the case of tin. By means of modern instruments, it is possible to compare the masses of atoms to one part in ten thousand, an accuracy which it is expected to increase in the near future. These isotopic weights are required in order to test theories of nuclear structure, which have recently become of the greatest importance on account of the discovery of transmutation and of artificial production of radioactive isotopes.

\section{Exploration of Nanda Devi}

NANDA Devr, with an altitude of $25,645 \mathrm{ft}$., in the Kumaun Himalayas, is supposed to be the highest mountain entirely within British territory. The area in which it lies is so rugged and unapproachable that even the base of the main peak defied assault until this year, though in 1907 Dr. T. G. Longstaff made an attempt via the Rishiganga gorge. In a letter to the Times of November 2, Mr. H. Ruttledge gives a preliminary account of an expedition to Nanda Devi led by Mr. E. E. Shipton this year. In June, with Mr. Tilman and a few native carriers, Mr. Shipton forced a way up the precipices of the Rishiganga gorge to the source of the river and explored the northern flank of Nanda Devi. Before the monsoon broke, they retreated northward and during July and August explored the Arwa, Bhagat-Kharak, and Satopanth glaciers before returning to their main task. Once more they ascended the Rishiganga gorge, mapped the southern basin of Nanda Devi, climbed a considerable distance up the peak and discovered a way that in the proper season would no doubt lead to the top. Finally, in September they crossed the difficult Sonadunga col and descended to the south. Mr. Shipton is returning to Great Britain next month.

\section{Sixty Years' Progress in Naval Construction}

SrR ARTHuR JoHNs, director of naval construction, for his Andrew Laing lecture to the North-East Coast Institution of Engineers and Shipbuilders on November 2, took for his subject "Progress in Naval Construction". Beginning with a comparison of the Navy in 1874 and 1934 , he dealt in turn with materials, the development of the capital ship and of cruisers, torpedo vessels, submarines, aircraft on warships, model experiments, welding and stability and strength. Nothing perhaps was more striking than the figures he gave regarding tonnage, horse-power and speed. The displacement tonnage of our fighting ships in 1874 was 825,000 as compared with $1,275,000$ of to-day, while the corresponding figures for horsepower are 590,000 and 9,500,000. A cruiser of 1874 had engines of 4,500 horse-power and a speed of 14 knots; a cruiser of to-day develops 72,000 horsepower and has a speed of $32 \frac{1}{2}$ knots. Though Sir Arthur Johns' review was necessarily a cursory one, it was a valuable authoritative review of the main lines of progress and contains references to many of the most interesting vessels ever launched. He paid an eloquent tribute to the work of William Froude, whose theory of a propeller's operation is still the simplest and most representative, and whose method of computing the skin resistance of full-sized ships has stood the severest tests. Regarding the stability of ships, this has been the bugbear of naval architects since the thirteenth and fourteenth centuries, and even after Bouquer had defined the meta-centre and shown how its position was determined, Atwood in a paper to the Royal Society proved to his own satisfaction that the meta-centre was a mere mathematical curiosity, useless to the naval architect. It was the researches of White and John after the capsising of the Captain in 1871 which made a marked advance in our knowledge of the stability of a ship and of the features which improve or adversely affect it.

\section{Coal Mining in Great Britain}

SiR RICHARD Redmayne delivered the presidential address to the Institution of Civil Engineers at the opening meeting of the new session on November 6 . Sir Richard has been for many years associated with coal mining in Great Britain, and it was appropriate that he should discuss aspects of the industry. In tracing its development, he pointed out that the growth of the railway and the application of steam 
to shipping gave a great impetus to the coal trade, the output in 1845 being three times that of 1800 . Great progress has been made during the past fifty years in the technique of coal mining, and in many collieries the only manual labour now used in the actual coal-getting is shovelling the machine-cut coal at the face on to a band- or jig-conveyor. In $1900,1.47$ per cent of the coal raised in Great Britain, and 24.9 per cent of that raised in the United States, was machine-mined; in 1932 the figures were 38 and $68 \cdot 3$ per cent respectively. Natural conditions in the United States, however, are better suited than those of many British coalfields to this mode of working. The methods of supporting the roofs and sides of underground roads are now undergoing considerable change; of the 20,000 miles of main roadways in coal mines of Great Britain, 1,800 miles are supported by steel arches, and there are in addition about 900,000 steel props used in and about the workings. The ultimate possible demand for steel supports in Great Britain is 370,000 tons a year, a quantity which would provide employment for at least 10,000 workers. Turning to the subject of accidents, Sir Richard said that, of the larger coal-producing countries, the most favourable figures are shown by France with a deathrate of 1.0 in a thousand; other figures are $1 \cdot 1$ for Great Britain and Belgium, and $4 \cdot 8$ (bituminous coal) and 3.9 (anthracite) for the United States. The future of the coal trade is dependent, in Sir Richard's view, on increased scientific research and the discovery of new uses for coal.

\section{University Degrees in Engineering}

IN the Engineer for November 2 is the first of a series of articles on "University Degrees in Engineering", and the subject is referred to in a leading article. One aspect of this question, namely, the new regulations for 'external' degrees in engineer. ing of the University of London, was discussed in NAture of August 12, 1933, p. 222. It is well known, says the Engineer, that regulations and customs governing the granting by British universities of degrees in engineering are not uniform, each university being a law unto itself. The values of degrees, therefore, differ greatly. While it is admitted that to ask the universities to reduce themselves to a dead level of uniformity as regards the standard of their products would be to aim a blow at the very root of the conception behind university instruction and education, yet it is impossible to shut one's eyes to the fact that some measure of standardisation of the conditions under which engineering degrees are granted is overdue. As an impartial observer, the Engineer considers that unless the problem is attacked thoroughly and soon, the reputation of university degrees for engineers will suffer a severe decline. How the regulations differ is shown in the first of the articles in the series, which deals with engineering degrees granted by the Universities of Glasgow, Aberdeen, Edinburgh and St. Andrews. The survey is based on information contained in official publications and it should be of use to those about to select a centre of engineering education and also to those called upon to assess the value of British engineering degrees or of those who hold them.

\section{Iron and Steel Institute: Co-operation with Local} Technical Societies

Arrangements have been made by the Council of the Iron and Steel Institute and the councils of various local technical societies for extending existing arrangements for co-operation between the Institute and such bodies. To this end, the Council of the Institute has agreed to extend the maximum age of associate membership from twenty-four years of age, as previously fixed, to thirty years of age in the case of associate members who are also members of local technical societies taking part in the scheme. It has also agreed to supply each year to the local societies, for presentation and discussion at local meetings, certain papers which have been presented at general meetings of the Iron and Steel Institute. One or two joint meetings each session between members of the local societies and members of the Iron and Steel Institute resident in the particular district will be arranged. It is hoped by these means usefully to extend the existing co-operation between the Institute and local technical societies, and particularly to encourage the study of problems connected with the manufacture and metallurgy of iron and steel, especially among the younger members of those societies. The secretary of the Iron and Steel Institute, 28 Victoria Street, London, S.W.1, will supply further information on request.

\section{Picture Telegraphy}

МетноDs of transmitting pictures by telegraphy have been known for the last ten years. In a suitably constructed photoelectric cell, the electric current through it can be made proportional to the light falling on it. If a picture in the form of a film negative be moved between a constant source of light and a cell in such a way that the light beam passes successively, line after line, through each minute area of the picture, the current transmitted will vary in intensity. The receiver is complicated, but the amount of light from a local source varies with the current received and falls on a photographic film which moves in step with the original film. A photoelectric cell can only distinguish light from darkness. Unlike the eye, it cannot distinguish form and colour. Photographs can be transmitted in this way by both wired and radio telegraphy. A recent remarkable achievement was the photograph of the Duke of Gloucester sent from Australia by the Marconi facsimile system of radio picture telegraphy. A still greater achievement was the transmission of the pictures on ten feet of cinematograph film showing the arrival of Scott and Campbell Black at Melbourne. An example of a news picture sent by the ordinary telegraph services between London and various Continental towns was the funeral of King Alexander at Belgrade. For ordinary commercial purposes, we think that picture telegraphy might be more widely used with advantage. Possibly the facilities it gives have not been sufficiently advertised. 